Volume 30, 2020

http://journals.sfu.ca/cjsdw

\title{
Article
}

\section{Notes on Anne Freadman's Tardy Response}

Janet Giltrow

University of British Columbia

So far, I have not been troubled by exigence, finding it a usefully modified version of motive. Now, though, following Freadman's analysis, I recognize that the concept can interfere with orderly accounts of change, and also with what people call mixture or hybridity, which themselves seem to bid for change. I can see uses for communities of use (Miller, 2017), although I prefer Bakhtin's (1986) "spheres of activity," with its focus on what groups of people do, rather than what they say. I realize now that my complacency about these terms-and others-may be owing to my habit of summoning them to introduce genre to a new audience, usually one likely to think of genre as formal structure, if they think of genre at all. Or to frame for a genre-familiar audience an entry to new but related concerns.

In Freadman's more philosophical and penetrating inquiry, I can see reasons to rethink, or refine, some longstanding principles. I realize I would have a hard time saying what social action is (cf. Freadman, 2020, p. 108). Does this idea come from Austin's (1962) speech acts, and their institutional dependency? Or is this an instance of hearing any utterance which can take a reporting verb (ask, assert, question, threaten...) as a speech act? Is social action "social" insofar as it is familiar to groups of people, and what part does familiar wording have to do with this social recognition? Others would have no trouble with these questions. But I wouldn't be confident addressing them. And what can count as a social action (or purpose or function) when these can rarely (if ever) be known in a definitive proposition? And when defining propositions do show up, can they only be loose approximations to serve the moment? For example, sociable and active, a host announces that dinner is served, and everyone heads for the table (rather than to the door). Is the announcement a genre, just because there are regularities in expression and in time and place? And who could say what action or purpose is accomplished by a dinner-party conversation, except in thin generalities: to renew or make new acquaintance? to eat? to boast? Any one of these could be easily contested and replaced, for none is proven or secured by expert inquiry; anybody could say these things, or other things instead, in getting at the social action. With these kinds of thin generalities on offer for social 
Volume 30, 2020

http://journals.sfu.ca/cjsdw

action, would anyone be convinced of the seriousness of genre theory? 1

Freadman's (2020) inspection of standby terms, like social action, is welcome and useful. And so is her observation that much of genre studies is conducted by classroom teachers who take an attitude of "pastoral care" (p. 112) towards their students. This cluster-classroom/genre/care-gives an opening to Bawarshi's observation of genre as a "seat of power" (Bawarshi, 2015, p. 181), and his discussion, citing Applegarth (2012), of genres being the "product of power-inflected historical choices" (p. 181). Power could open the door to Freadman's (2020) uptake of Lyotard's metaphorical "tribunal" and jurisdiction, but without an overarching, universal "law" of gene. However, Freadman does not take up Bawarshi's and Applegarth's reports of power. Thus, she avoids their implying the individual-which, according to Freadman, has no place in genre theory (pp. 119120).

And neither does "pastoral care," about which Freadman (as far as I can tell) is skeptical. Yet that "care" plays a role in the teacher's story cited by Freadman (pp. 114). The teacher tells how, after a classmate's suicide, the "old," "now dead" principal unfeelingly dictates the limits of the students' speaking roles. The story brings to the table the longstanding issue of genres limiting or allowing speech. However, I am puzzled by this story. The genre at stake-which must be elegy, obituary, something like that-does authorize speech; but the principal says there will be no such speaking. The principal, not the genre, excludes the students' voices. Back in the classroom, the teacher, in the spirit of pastoral care, re-authorizes the students' speech, by, according to the story, speaking herself. The students aren't reported as having said anything, even after being authorized. The place to take up this story may be not at genre but at the intersection of authorization and pastoral care, with genre as a proxy for these.

Both care and compliance suggest duress. Duress can also be found in, for example, courtroom as well as classroom genres. The genres of courtroom questioning, as one instance, permit witnesses to speak only under deeply constrained conditions: not only those of court procedures but also of counsel's strategy. Where speakers can be embarrassed or even penalized for non-compliance, people can detect 'gatekeeping': the genre wards off certain would-be speakers from certain types of activities and roles. A central claim of Canagarajah's (2002) The Geopolitics of Academic Writing develops from such analysis, taking it so far as to imagine deliberate and clandestine changing of

\footnotetext{
${ }^{1}$ Respectfully, and appreciating Freadman's identifying ceremonials, I regard the book jacket and the start-up of a public lecture as both visible from a distance and from ordinary experience-as are my examples of a call to the table (ceremonial) and a dinner-party conversation (genre). I have not made an expert study of either, but rely on my readers to recognize from ordinary experience what I am talking about.
} 
Volume 30, 2020

http://journals.sfu.ca/cjsdw

rules to keep the gate in good repair-for keeping out unwelcome speakers. In turn, the gatekeeping conceit depends on genres being composed of rules rather than experiences of interaction.

Onerous as rule-giving and compliance may be, even calling for pastoral consolation, Freadman nevertheless presents an appealing, gentle-minded version of rule-giving, in her reminiscence of the ancient classroom of Quintilian (Freadman, 2020, pp. 125-126). In that classroom, the rules given out by the professor transfer easily to public space. Following these rules, students become authorized speakers, carrying with them abundant "resources": samples of mature, successful performance in the public genres. Compare first-year composition class with its rules from the professor and the examples of "expository" writing or "personal essay." These fall short of Quintilian's examples, which set students on a well-marked path to authorized public performance. The path forward from the composition anthology is obscure rather than well-marked. Nowadays, topics will be science and social issues eligible for popularization, in place of the more canonical instances of earlier anthologies: for example, King's "Letter from Birmingham Jail," Orwell's "Politics and the English Language," Woolfs "Death of a Moth." These are "resources" students are presumed to carry forward-but are more likely to leave behind, in "English" class.

With this plan for students to get resources in the classroom and carry them forward into their "real lives," the genres in question may still have to be imagined as separable from (a possibly equally imaginary or idealized) context. Beyond the reach of the classroom, a genre may have to be known as similarly able to be isolated for study and analysis (I have done this, even as I denied the possibility of genres being separated from surrounding utterance and sociality). Analysts can designate and uproot the genre. Doing so, they overlook Miller's (1984) early declaration that the conceptualization and study of genre is not for taxonomic purposes.

Further, even terms and measures seeming more innocent (moves, for example, is more lively than form) - even those terms which seem more hospitable to change and flexibility-still presuppose an entity which can be isolated from surrounding discourse, and can change, on its own. So hybridity, mix, multi-modality, even change itself, all presuppose something discrete enough to become part of a hybrid composition or, like a kitchen ingredient, to blend into something else; or the terms presuppose something recognizable enough by itself to be seen showing up-as if by its own accord-in non-traditional modes. And what happens to the enduring commonplace about genres' forms being so stable as to host "creativity" and "invention" (Freadman, 2020, p. 109)? What are the arrangements between the strict host and its fickle guest? These models may help to explain-to others, and even to ourselves-how language works, where it stands. Some phenomena are difficult 
Volume 30, 2020

http://journals.sfu.ca/cjsdw

to explain, or study. Their boundaries, features, and functions never stay still and pose for inspection and description.

Yet making these phenomena accessible to inquiry by isolating and formalizing them-this comes at a cost. We might notice that, typically, scholarship draws on examples of genres that already stand out from everyday speech: law, sermons, theatre. Even Bakhtin (1986) turned to "criminal argot," an exorbitant example of utterance isolated from everyday exchanges. Similarly, English for Special Purposes (ESP) has supported the idea of genres as themselves something special, noticeable for their being easily singled out from other, putatively non-generic speech, and easy to pluck from their habitats. When "context" arrives to give genre its special purpose, it can be little more than a shell which contains and separates a genre from its surroundings: the connecting interaction of its speakers. Once separated and named, the genre can be positioned in an abstract system. In this process, the most pressing question is: How could speakers get to know and use a form-from a generalized, abstract system? Miller's (2015) "social recognition" (p. 175) excuses language-users from apprehending a system, but still leaves "social" closed to other questions about its nature.

In Freadman's rhetorical genre theory there is no role for individual consciousness-even in the now-famous "social recognition." Overlooking individual consciousness comes at the cost of overlooking a plausible explanation for change. Taken up in individual consciousness, genres are no longer matters of regulations, although they still show degrees of regularity. Entertained in individual consciousness, genres are subject to the vicissitudes of people's individual experience of the world, rather than being formal, inactive objects of study or stricture. For example, the devoted adherent to a faith will know the genre "sermon" differently from an unwilling child listener. Regularities across occasions (or the fact of regularities) will inspire different interpretations, despite the utterance's social recognition. The sensation of exigence will not be the same for each Hearer, let alone for the sermonizer.

From some points in Freadman's (2020) analysis, a field beyond the formal domain can be glimpsed. While still a generality, the "feedback loop" (p. 112), an extension of the "dynamics of communication," could be read as offering a step down from abstract form (a step recommended by Bakhtin, 1986, pp. 69-70). "Intergenerational teaching" also involves minds meeting, though the exchange is lopsided, and the "teaching" may only consolidate schoolroom form and dictates across generations. Aside from formal teaching, I ask again, how can speakers get to know and use genres from generalized abstractions of form? Bakhtin's (1986) "actively responsive understanding," "very 
Volume 30, 2020

http://journals.sfu.ca/cjsdw

complexly organized chain of other utterances" (p. 69) is taken up by Freadman (2020) as the "responsive chains" (p. 113). Bakhtin warns that, if the generality of the chain is adopted, it becomes a "fiction" (Bakhtin, 1986, pp. 69-70). The actuality of the linking is in "concrete" utterances and concrete efforts at mutual understanding. Genre, then, is what is rendered in the particular interactions in spheres of activity and cannot be known by formal inquiry (we now rarely hear the old-time assertion that "genre knowledge" is "tacit"). Abstractions can describe genres' enduring continuity, and their changes and mixing, only in fictions.

More engaged mentalities are suggested by Miller, as cited by Freadman (2020, p. 111). In the process of ridding rhetorical agency of subject, Freadman recalls Miller's (2001) "interface of human interaction" in rhetorical situations (p. 255). For Miller (2007), in rhetorical situations there are "at least two subjects"; through their interaction they make "attributions [...] about each other and understand each other to be making [attributions]" (p. 150). This axis of attributions constitutes rhetorical agency. Freadman (2020) rejects Miller's formulation for its implication that there is "a distinction between subjectivity and agency" (p. 111), in which subjects constitute agency through the medium of interaction. The notion of the subject can, in Freadman's (2020) view, mistakenly introduce to genre studies ideas of "[motivation] by the forces of the unconscious" (p. 111). Genre doesn't need a theory of the individual.

Miller's proposal can no doubt defend itself on its own. I will try to advance it rather than defend it. Miller's proposal can redirect the gaze of genre theory from the costs and benefits of form to the materials of consciousness. Genre theory may improve its own theory of consciousness or develop one from scratch. In the meantime, there is at hand a linguistic model of consciousness suited to study of genre. ${ }^{2}$

Owing no service to system or form, linguistic pragmatics traces its pedigree to Wittgenstein and Austin, and, most notably, to Grice's (1967/1989) "Logic and Conversation," as well as to other philosophers in the Ordinary Language school (notably, Horne, Sperber and Wilson, and Levinson; and working currently, Carston and Recanati).

An early and well-known example 3 is:

Speaker: The window is open.

\footnotetext{
${ }^{2}$ I have already introduced aspects of this model to genre study, more than once. There has been no uptake. At the risk of being ridiculous, I try again.

${ }^{3}$ Cf. Derrida, as taken up by Freadman (2012), also shows function's independence of form, but misses elements of the pragmatic analysis demonstrated below. However, the window is shared.
} 
Volume 30, 2020

http://journals.sfu.ca/cjsdw

The Speaker is silent on their expectation that stating that the window is open will lead the Hearer to infer that the Speaker "means" something, such as (a) that the Hearer should close it; (b) that the open window is the cause of the room being cold; or (c) that the open window is evidence of an intruder (among other possibilities). Getting at the Speaker's intention (including discarding possibilities like (b) and (c)) is to get to the "meaning" of the utterance; the meaning of the utterance is not its literal, dictionary-supported meaning or its propositional content, but the intention of the Speaker inferable by the Hearer. 4

Using the terminology of linguistic pragmatics, it is owing to their common ground in the conversation that the Speaker and the Hearer can both know which window is at stake-which window the Speaker "means." But it is only by means of mutual knowledge that the Hearer can infer the silent intention that the Speaker wants them to close the window. Both know the window as common ground, but that does not enable the Hearer to infer "close the window" as the Speaker's silent intention. The Speaker and the Hearer must mutually know what makes the statement relevant (why say that the window is open when both can see an open window?). How does the Hearer infer that the Speaker's intended meaning is "close the window"? Perhaps in this instance, the Hearer knows that the Speaker is bed-ridden, "needy," paying the Hearer for care. And that knowledge is mutual: The Hearer knows that the Speaker knows this, and the Speaker know that the Hearer knows that the Speaker knows that the Hearer knows this... and so on. In pragmatics, common ground was soon replaced by mutual knowledge, which was in turn dismissed for failure to meet philosophical standards of calculation. We can rescue mutual knowledge and put it to work in genre studies and genre theory. In doing so, it is important to note how mutual knowledge is more than shared knowledge, or common ground.

Speaker: Two 20-unit condominium buildings have been proposed for the corner.

Hearer: Too many changes.

What corner? Common ground could answer this question. For example, if the exchange takes place at a crosswalk signal from which "the corner" is visible and apparent, the Speaker and the Hearer share this knowledge; similarly, if the exchange takes place at a public hearing, the agenda, shared by all attendees, will point to the corner in question. In both cases, there is common ground.

\footnotetext{
4 The Hearer's response to the Speaker is motivated by Grice's (1967/1989) "Cooperative Principle." The Cooperative Principle has been an object of scrutiny as some thinkers take Grice's use of "cooperation" in the technical sense, while others take it in the more everyday sense, which is used, of course, for uncountable everyday situations. It is the technical sense which could be adapted to Genre Theory.
} 
Volume 30, 2020

http://journals.sfu.ca/cjsdw

With mutual knowledge, pragmatic analysis goes further. Taking a chance, the Speaker at the corner estimates that the Hearer knows which corner; the Hearer estimates that the Speaker estimates that the Hearer knows which corner. So the Hearer interprets "the corner" as having to be a corner which the Speaker could know that the Hearer probably knows; the Speaker estimates that the Hearer estimates that "the corner" is intended to mean a corner that the Speaker can estimate that the Hearer is estimating that the Speaker is estimating ... and so on. At "so on," philosophers (and others, probably) object, finding this long series not feasible. How can the Speaker/Hearer pair ever estimate mutual knowledge-one another's awareness and assumptions-even in this simple textbook-style case, to the point that there can be no mistake? Immediately (as conversation requires) or at length (as poems and statutes can require)?

Even with the series of mutual estimates, there is still risk in the public version, but it is much smaller due to the exchange taking place within the genre of the city-sponsored public hearing, with its agenda and its inviting response to change. Small talk presents bigger problems in estimating mutual consciousness: what the Hearer has in mind or can reasonably bring to mind. For many interactions, the genre in which it takes place improves the Speaker's and the Hearer's estimates of the consciousness of one another: insofar as each "knows" (in some way) the genre at stake, each can reasonably estimate the focus, frame of mind, and assumptions-together, the consciousnessof the other.

Relevance Theory (as developed by Sperber and Wilson, 1995, among others) is applicable here. Relevance Theory elaborates one element of Grice's "logic": Be Relevant. Extending the mutual estimates of the other's consciousness (what they know the other knows, etc.) is the criterion of Relevance. To take just one step in the chain of reasoning, the Hearer estimates what the Speaker could reasonably estimate as relevant to the Hearer-that is, what can contribute in some way to the Hearer's knowledge of the world. Once a reasonable estimate is reached (often right away), the chain of reasoning stops, for it would be irrational and a waste of effort to continue it. Mutual knowledge of genre would support even strangers inferring one another's frame of mind; Genre Theory and Relevance Theory could help each other.

Mutual knowledge of a genre improves the chances of the Speaker and the Hearer correctly estimating one another's frame of mind and supports the mutual inferring of intention and meaning. But even then, the estimates cannot be guaranteed, and the analysis still cannot answer the philosophical criticism that we can never ascertain others' consciousnesses. Yet we have no evidence that communication depends on the kind of certainty that can be demonstrated by philosophical 
Volume 30, 2020

http://journals.sfu.ca/cjsdw

calculation. As I have said elsewhere (too often), every utterance is an experiment in estimating the consciousness of another.

Some theorists in pragmatics have indirectly refused genre as they continue to dismiss what we have retrieved from the dustbin and continued to call mutual knowledge. This reaction may have to do with neo-Gricean pragmatics' reliance on snippets, usually domestic or personal (e.g., the window), or street-level (e.g., the crosswalk) to demonstrate inference. So, for example, Marmor (2008) claims that neo-Gricean pragmatics cannot deal with legal genres, which lack the "rich" contextual background shown in brief personal snippets. Yet as I have suggested above, it is small talk that takes a risk in estimating shared context. Small talk (what Bakhtin may have had in mind with 'primary genres') provides less rather than more evidence of the state of mutual knowledge..

In turn, genres may inform the range of inference to be drawn. An example (adapted from Levinson, 1979, to be discussed below) is the primary-school genre of classroom questioning by the teacher. What animal looks like a horse but has stripes?- the answer "zebra!" is to be interpreted as evidence of the pupil knowing about zebras, not as providing information to a teacher who did not know which animal both resembles a horse and has stripes. (And the pupil knows the teacher knows this, and the teacher knows the pupil knows they know... They are mutually knowledgeable about the genre.) Aesthetic genres-still low-hanging fruit for genre theorists reaching for examples-mostly arrange for longer series of attempts at estimating intended inferences: the Speaker's estimates of the Hearer's consciousness, the Hearer's estimates... and so on, combined with surrounding elements that are estimated by the Speaker to have stayed in mind and to be accessible for allusions, for example. Conceptual visual art, often untitled, may set up a precipitous path to inference (why is this artist showing this to us, now? Even, what is it?). And the accessibility of inference-short or long chain of attempts-may distinguish genres: Aesop's fables from Beckett's Malone Dies. And some genres may support their own style of inference: for example, literary genres may be taken up as allowing one conclusive declaration of author's intention to be replaced by another equally emphatic one, later. Statutes and scripture support their own practices of inference, limiting the range. And while these examples may be extreme, parallel socio-cognitive conditions are typical of, rather than rare in, everyday interaction. Consider Wittgenstein's “Slab!” (1958, 4, §6). For the Overhearer, the meaning of "Slab!" cannot be known from a dictionary, only from observation of the situation. But its thorough meaning comes only from its being addressed to a Hearer whose consciousness has been estimated by the Speaker, and from the Hearer's estimation of the consciousness of the Speaker as having estimated this consciousness: the Hearer's capacity, at that 
Volume 30, 2020

http://journals.sfu.ca/cjsdw

moment, to infer the Speaker's intention, that is, the meaning of "Slab!". When this chain stops (probably very quickly), the worker bends to lift a slab.

John Searle (1976) bypassed this kind of analysis, to arrive at his goal of developing core meanings, so-called felicity conditions, for structures. In 1979, Stephen Levinson dismissed Searle's formalist development of Austin's (1962) speech act model. For example (and the main example), Searle aimed to pin down the 'felicity conditions' for the speech structure question: what counts as a question? what has to be going on for a question to be felicitous? Levinson's own example of classroom questioning shows Searle's project as radically mistaken (and as challenging the typical collocation "Austin-and-Searle"). Some of Levinson's examples, being more typical of the snippets examined in pragmatics, may slip below what we sometimes take to be the threshold of genre (e.g., buying a lettuce). Others, however, such as the classroom questioning, are genres, and the genres guide the Speakers' and the Hearers' interpretation of the structure and, accordingly, their inferences about intention and meaning. Levinson (1979) confronts the problem of mutual knowledge (where would one even start figuring out the mind of another? where would one end?) by proposing the "reciprocity" of the inferable (p. 376) — the reciprocity secured by the "activity type." As far as I know, Levinson is the only pragmatic-linguist to follow Wittgenstein's lead, to step squarely into a space visible from genre theory. ${ }^{5}$ And Levinson himself, despite his advances, may share the weaknesses of some genre theory: namely, that genres are what stand out from everyday interaction (cf. ESP), the marked case showing itself above the unmarked baseline.

The snippets illustrating pragmatic models do not line up with the illustrations of genre that we are used to. But their focus on consciousness rather than form is an opportunity for explanations other than formalist ones for genres' ability to change, mix and blend, or "bend," as well as for their efficiency and continuity. And if the snippets convincingly demonstrate socio-cognitive principles of interaction, genre theory and genre study should not overlook the pragmatic analysis.

\section{References}

Applegarth, A. (2012). Rhetorical scarcity: Spatial and economic inflections on genre change. College Composition and Communication, 63(3), 453-483.

Austin, J. L. (1962). How to do things with words. Oxford, UK: Oxford University Press.

${ }^{5}$ In my view, historical pragmatics may be an exception. My view is not authoritative. 
Volume 30, 2020

http://journals.sfu.ca/cjsdw

Bakhtin, M. M. (1986). The problem of speech genres (V. W. McGee, Trans.). In C. Emerson \& M. Holquist (Eds.), Speech genres and other late essays (pp. 60-102). Austin: University of Texas Press.

Bawarshi, A. (2015). Accounting for genre performances: Why uptake matters. In N. Artemeva \& A. Freedman (Eds.), Genre studies around the globe: Beyond the three traditions (pp. 186-206). Edmonton, AB: Inkshed.

Canagarajah, A. S. (2002). A geopolitics of academic writing. Pittsburgh, PA: University of Pittsburgh Press.

Freadman, A. (2012). The traps and trappings of genre theory. Applied Linguistics, 33(5), 544-563. doi:10.1093/applin/ams050

Freadman, A. (2020). A tardy uptake. Canadian Journal for Studies in Discourse and Writing/Rédactologie, 30, 105-132. doi: 10.31468/cjsdwr.781

Grice, P. (1989). Logic and conversation. In Studies in the way of words (pp. 22-40). Cambridge, MA: Harvard University Press. (Original lecture given 1967).

Levinson, S. C. (1979). Activity type and language. Linguistics, 17(5-6), 365-399. doi:10.1515/ling.1979.17.5-6.365

Marmor, A. (2008). The pragmatics of legal language. Ratio Juris, 21(4), 423-452. doi:10.1111/j.1467-9337.2008.00400.x

Miller, C. R. (1984). Genre as social action. Quarterly Journal of Speech, 70(2), 151-167. doi:10.1080/00335638409383686

Miller, C. R. (2001). Writing in a culture of simulation. In P. Coppock (Ed.), The semiotics of writing: Transdisciplinary perspectives on the technology of writing (pp. 253-280). Turnhout, Belgium: Brepols.

Miller, C. R. (2007). What can automation tell us about agency? Rhetoric Society Quarterly, 37(2), 137-157. doi:10.1080/02773940601021197

Miller, C. R. (2015). Genre change and evolution. In N. Artemeva \& A. Freedman (Eds.), Genre studies around the globe: Beyond the three traditions (pp. 154-185). Edmonton, AB: Inkshed.

Miller, C. R. (2017). “Where do genres come from?”. In C. R. Miller \& A. R. Kelly (Eds.), Emerging genres in new media environments (pp. 1-34). Cham, Switzerland: Palgrave Macmillan. doi:10.1007/978-3-319-40295-6_1

Searle, J. R. (1976). A classification of illocutionary acts. Language in Society, 5(1), 1-23. 
Volume 30, 2020

http://journals.sfu.ca/cjsdw

Sperber, D., \& Wilson, D. (1995). Relevance: Communication and cognition (2nd ed.). Oxford, UK: Blackwell.

Wittgenstein, L. (1958). Philosophical Investigations (G. E. M. Anscombe, Trans., 2nd ed.). Oxford, UK: Blackwell \& Mont, Ltd. 